\title{
Antibiogram of Bacterial Isolates from Bubaline Subclinical Mastitis
}

\author{
Arpit Tyagi $^{1 *}$, Richa Arora ${ }^{2}$, V.S. Rajora ${ }^{1}$ and Niddhi Arora ${ }^{1}$ \\ ${ }^{I}$ Department of Veterinary Medicine, CVASc, Pantnagar, Uttarakhand, India \\ ${ }^{2}$ Department of Animal Biotechnology, IVRI Izatnagar, Uttar Pradesh, India \\ *Corresponding author
}

\section{A B S T R A C T}

\section{Keywords}

Antibiogram, Bacteria, Buffalo, Sub-clinical mastitis, Prevalence

Article Info

\section{Accepted:}

04 October 2020

Available Online:

10 November 2020
The present investigation was carried out to study the prevalence of bacterial pathogens responsible for subclinical mastitis in buffaloes in and around Pantnagar in the state of Uttarakhand, India and the antibiogram pattern of the bacterial isolates to selected antibiotics. A total of 109 buffaloes were screened for SCM based on physical examination of udder, California mastitis test (CMT), Somatic cell count (SCC) and Differential cell count (DCC) on quarter's milk samples. The quarter's milk samples showing CMT reaction $\geq 2, \mathrm{SCC} \geq 0.5 \mathrm{million} / \mathrm{ml}$ and neutrophils percentage $\geq 40 \%$ of total counts were considered for identification of major pathogens involved. Milk samples from affected quarters were subjected to cultural and biochemical examination for isolation and identification of bacterial pathogens. Antibiogram profile of each bacterial isolate to standard antimicrobial discs was determined by agar diffusion method. Staphylococcus aureus were the most common isolates of subclinical mastitis in dairy buffaloes, followed by streptococci other than $S$. agalactiae, Coagulase negative staphyllococus and $S$. agalactiae isolates respectively. The overall antibiogram of the major bacterial isolates revealed the highest sensitivity to enrofloxacin $(86.5 \%)$, followed by cefotaxime $(82.0 \%)$ and amoxycillin/clavulanic acid $(80.9 \%)$. The current work enables selection of proper antibacterials for treatment of mastitis in the study area.

\section{Introduction}

Mastitis, inflammation of the mammary gland, is preeminent and expensive disease of dairy animals globally. Pathological alterations in the glandular tissues along with physico-chemical and bacteriological changes in milk are the prominent features of mastitis (Radostits et al., 2007). It could occur in clinical, sub-clinical and chronic form; based on the severity of infection and type of inflammation. However absence of gross inflammation of the gland and major observable abnormalities in milk makes it difficult to detect sub-clinical mastitis. Often ignored, sub-clinical mastitis has a severe economic implications associated with reduced milk production (Viguier et al., 2009). It has been estimated in India that subclinical mastitis contributes approximately $60 \%$ to the economic setback suffered by dairy sector due to mastitis (Bansal and Gupta, 2009). Both infectious and noninfectious agents could cause mastitis. 
Bacteria, yeasts, mycoplasma and various other microbes have been implicated as mastitis causing pathogens (Bradley, 2002). However, intramammary bacterial infection is the major cause of mastitis in dairy animals (Zhao and Lacasse, 2008). Proper microbial diagnosis, prevalence study in the herd and appropriate selection of antimicrobial agents based on antibiotic sensitivity are significant for successful and efficient management of sub-clinical mastitis. Keeping the above facts in mind, the present investigation was carried out to study the incidence of bacterial pathogens responsible for subclinical mastitis in buffaloes and the antibiogram pattern of the isolates to selected antibiotics.

\section{Materials and Methods}

The study was conducted on lactating buffaloes of Murrah breed from both organized and unorganized dairy farms in and around Pantnagar located in the Terai region of Himalayas in the state of Uttarakhand, India. A total of 109 buffaloes were screened for SCM on the basis of physical examination of udder, California mastitis test (CMT), Somatic cell count (SCC) and Differential cell count (DCC) on quarter's milk samples. The quarter's milk samples showing CMT reaction $\geq 2, \mathrm{SCC} \geq 0.5 \mathrm{million} / \mathrm{ml}$ and neutrophils percentage $\geq 40 \%$ of total counts were considered for identification of bacterial pathogens involved. The quarter's milk samples positive on basis of CMT, SCC, DCC and confirmed positive for intramammary infection were classified into subclinical mastitis as per International Dairy Federation criteria for subclinical mastitis while those with inflammatory response but negative on culture examination were classified into nonspecific mastitis. Milk samples from the affected quarters were subjected to cultural and biochemical examination for bacterial isolation and identification (Quinn et al., 2004). Antibiogram profile of each bacterial isolate to standard antimicrobial discs was determined by agar diffusion method using 21 commercially available anti-bacterial sensitivity discs (Bauer et al., 1966). Results of anti-microbial sensitivity were interpreted as sensitive, intermediate or resistant and are expressed as percentage sensitivity to each antibacterial agent.

\section{Results and Discussion}

A total of 426 quarters from 109 lactating buffaloes have been investigated of which, 117 quarters from 41 buffaloes were screened positive SCM. Out of these 117 quarter's milk samples screened positive to CMT, SCC and DCC, 83 milk samples from 41 buffaloes were found culturally positive for either single or mixed bacterial infection and classified into subclinical mastitis while 34 samples showed no growth on culture medium and classified into non-specific mastitis. A total of 113 isolates were identified based upon culture and biochemical characteristics out of which Staphylococcus aureus were the most common isolates of subclinical mastitis in dairy buffaloes, followed by streptococci other than $S$. agalactiae, Coagulase negative staphyllococus and $S$. agalactiae isolates respectively. A relative distribution of bacterial pathogens of subclinical mastitis in dairy buffaloes in Pantnagar is depicted in Fig. 1.

Staphylococci were found to be the foremost etiological agent of disease and its high prevalence has been reported by several workers in India (Ali et al., 2015 and Sharma et al., 2018) and abroad (Hamed and Ziatoun, 2014; Elsayed et al., 2015). Streptococci were the second most prevalent causative agent of bubaline mastitis in and around Pantnagar. This is in close agreement with the findings of Khan et al., (2004) and Sharma and Sindhu (2007). On the contrary, Kumar et al., (2007) 
and Jhambh et al., (2017) reported Streptococci to be more prevalent than Staphylococci. In the present study, $8.41 \%$ of cases sub clinical bubaline mastitis was due to E. coli infection. Sharma and Sindhu (2007) also recorded comparable occurrence of coliform mastitis in buffaloes whereas Awandkar et al., (2009) have reported higher incidence of $E$. coli infections $(40 \%)$ in bovine mastitis. Coliform mastitis is indicative of poor hygienic conditions (Sumathi et al., 2008). Staphylococcus aureus and Streptococcus agalactiae are the most frequent contagious pathogens of bovine mammary gland. S. aureus is chief pathogen responsible for SCM in dairy animals (Radostits et al., 2007) while S. agalactiae is a noteworthy cause of chronic mastitis where control measures for contagious mastitis have not been properly implemented (Keefe, 1997). Thus, the present investigation reveals the preponderance of the contagious form of subclinical mastitis at the farm that needs to be restricted with apt preventive measures to check further spread. Whereas, a lower prevalence of SCM due to E. coli and other environmental pathogens (Radostits et al., 2007) is suggestive of the improved sanitation and hygienic practices at the farm.

Table.1 Overall Antibiogram profile of major bacterial pathogens of subclinical mastitis in dairy buffaloes in and around Pantnagar

\begin{tabular}{|l|c|c|c|c|c|}
\hline \multicolumn{1}{|c|}{ Antimicrobial agent } & $\begin{array}{c}\text { Staph. } \\
\text { aureus }\end{array}$ & CoNS & $\begin{array}{c}\text { Strep. } \\
\text { agalactiae }\end{array}$ & $\begin{array}{c}\text { Other } \\
\text { streptococci }\end{array}$ & Overall \\
\hline Amoxycillin & $(\mathbf{2 6})$ & $(\mathbf{2 3})$ & $(\mathbf{1 5})$ & $(\mathbf{2 5})$ & $\mathbf{( 8 9 )}$ \\
\hline Amoxycillin/Clavulanic acid & $\mathbf{1 7 ( 3 4 . 6 \% )}$ & $5(21.7 \%)$ & $8(53.3 \%)$ & $12(48.0 \%)$ & $34(38.2 \%)$ \\
\hline Amoxycillin/Sulbactum & $12(46.1 \%)$ & $19(82.6 \%)$ & $15(100 \%)$ & $21(84.0 \%)$ & $72(80.9 \%)$ \\
\hline Ampicillin & $9(34.6 \%)$ & $6(26.1 \%)$ & $6(40.0 \%)$ & $10(40.0 \%)$ & $31(34.8 \%)$ \\
\hline Ampicillin/Cloxacillin & $11(42.3 \%)$ & $6(26.1 \%)$ & $9(60.0 \%)$ & $15(60.0 \%)$ & $41(46.1 \%)$ \\
\hline Ampicillin/Sulbactum & $17(65.3 \%)$ & $11(47.8 \%)$ & $11(73.3 \%)$ & $18(72.0 \%)$ & $57(64.0 \%)$ \\
\hline Cefotaxime & $19(73.1 \%)$ & $22(95.6 \%)$ & $11(73.3 \%)$ & $21(84.0 \%)$ & $73(82.0 \%)$ \\
\hline Ceftriaxone & $18(69.2 \%)$ & $18(78.2 \%)$ & $12(80.0 \%)$ & $22(88.0 \%)$ & $70(78.6 \%)$ \\
\hline Clindamycin & $13(50.0 \%)$ & $22(95.6 \%)$ & $12(80.0 \%)$ & $18(72.0 \%)$ & $65(73.0 \%)$ \\
\hline Cloxacillin & $10(38.4 \%)$ & $11(47.8 \%)$ & $12(80.0 \%)$ & $19(76.0 \%)$ & $52(58.4 \%)$ \\
\hline Enrofloxacin & $22(84.6 \%)$ & $23(100 \%)$ & $14(93.3 \%)$ & $18(72.0 \%)$ & $77(86.5 \%)$ \\
\hline Erythromycin & $15(57.7 \%)$ & $22(95.6 \%)$ & $12(80.0 \%)$ & $15(60.0 \%)$ & $64(71.9 \%)$ \\
\hline Gentamicin & $16(61.5 \%)$ & $14(60.8 \%)$ & $10(66.6 \%)$ & $15(60.0 \%)$ & $55(61.7 \%)$ \\
\hline Lincomycin & $13(50.0 \%)$ & $20(86.8 \%)$ & $12(80.0 \%)$ & $19(76.0 \%)$ & $64(71.9 \%)$ \\
\hline Methicillin & $13(50.0 \%)$ & $6(26.1 \%)$ & $10(66.6 \%)$ & $22(88.0 \%)$ & $51(57.3 \%)$ \\
\hline Neomycin & $20(76.8 \%)$ & $18(78.2 \%)$ & $13(86.6 \%)$ & $18(72.0 \%)$ & $69(77.5 \%)$ \\
\hline Ofloxacin & $10(38.4 \%)$ & $13(56.5 \%)$ & $9(60.0 \%)$ & $14(56.0 \%)$ & $43(48.3 \%)$ \\
\hline Penicillin G & $5(19.2 \%)$ & $5(21.7 \%)$ & $6(40.0 \%)$ & $10(40.0 \%)$ & $26(29.2 \%)$ \\
\hline Rifampicin & $17(65.3 \%)$ & $17(73.9 \%)$ & $12(80.0 \%)$ & $21(84.0 \%)$ & $67(75.2 \%)$ \\
\hline Streptomycin & $16(61.5 \%)$ & $14(60.8 \%)$ & $14(93.3 \%)$ & $19(76.0 \%)$ & $63(70.7 \%)$ \\
\hline Tetracycline & $14(53.8 \%)$ & $14(60.8 \%)$ & $10(66.6 \%)$ & $15(60.0 \%)$ & $53(59.5 \%)$ \\
\hline
\end{tabular}


Fig.1 Relative distribution of bacterial pathogens of subclinical mastitis in dairy buffaloes

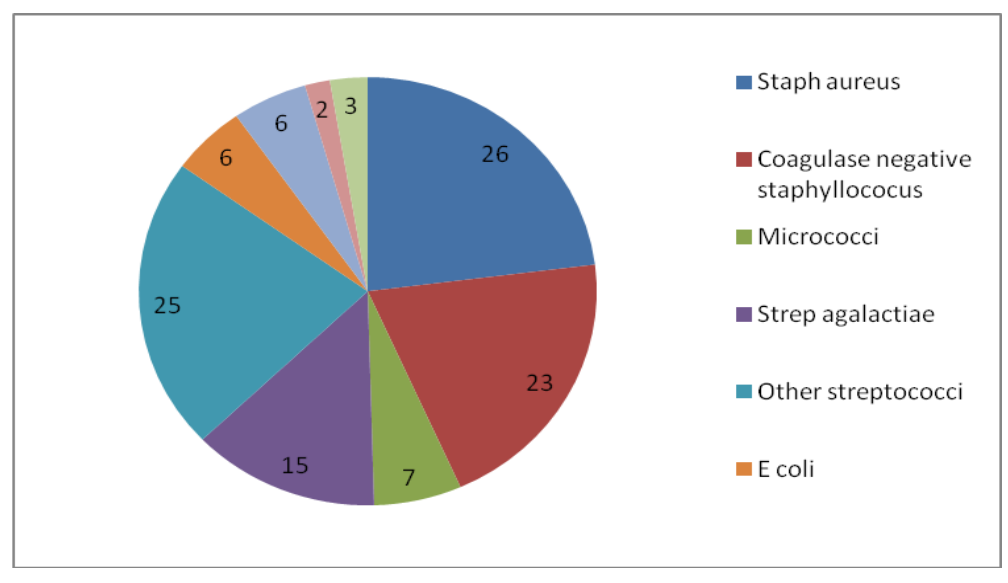

Fig.2 Antibiogram profile of major bacterial pathogens of subclinical mastitis in dairy buffaloes in and around Pantnagar

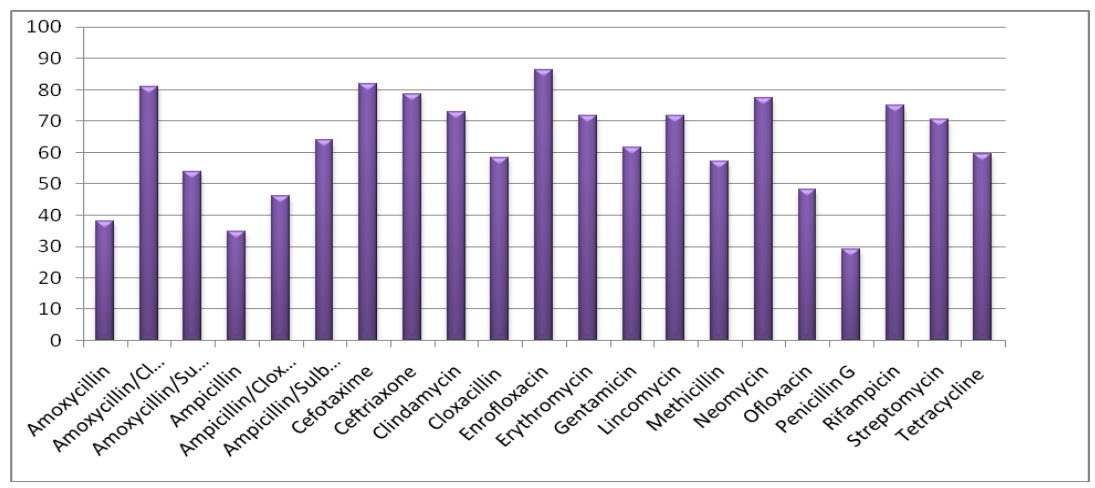

Percent antimicrobial sensitivity of major bacterial isolates of mastitic milk in and around Pantnagar is depicted in table 1 and figure 2. The antibiogram of the Staphylococcus aureus isolates revealed the highest sensitivity to enrofloxacin followed by neomycin, cefotaxime, ceftriaxone, amoxycillin/clavulanic acid, ampicillin/ sulbactam, rifampicin, gentamicin, streptomycin, erythromycin, tetracycline, lincomycin, clindamycin, methicillin, amoxycillin/ sulbactam, ampicillin/ cloxacillin, cloxacillin, ofloxacin and least sensitivity to amoxycillin, ampicillin and penicillin G.

Enrofloxacin was effective against $100 \%$ isolates of Coagulase negative Staphylococci.
Amoxycillin/clavulanic acid (100\%) followed by Enrofloxacin and Rifampicin were highly effective against Streptococcus agalactiae while against other Streptococci species other than Streptococcus agalactiae, methicillin and ceftriaxone were most effective followed by amoxycillin/clavulanic acid and cefotaxime.

The overall antibiogram of the major bacterial isolates revealed the highest sensitivity to enrofloxacin (86.5\%), followed by cefotaxime (82.0\%), amoxycillin/clavulanic acid (80.9\%), ceftriaxone (78.6\%), neomycin (77.5\%), rifampicin $(75.2 \%)$, clindamycin $(73.0 \%)$, lincomycin (71.9\%), erythromycin (71.9\%), streptomycin $(70.7 \%)$, ampicillin/sulbactam $(64.0 \%)$, gentamicin (61.7\%), cloxacillin (58.4\%), methicillin (57.3\%), amoxycillin/ 
sulbactam (53.9\%), ofloxacin (48.3\%), ampicillin/cloxacillin (46.1\%) and least sensitivity to amoxycillin (38.2\%), ampicillin (34.8\%), and penicillin $\mathrm{G}(29.2 \%)$.

Tripathi (2015) studied the antimicrobial sensitivity pattern of bacterial isolates of subclinical mastitis in cows at the same farm which also showed the highest sensitivity to enrofloxacin and cefotaxime. Somewhat similar antibiogram pattern of bacterial isolates has been recorded by Bhanot et al., (2012) and Ali et al., (2015). Poor sensitivity to penicillin $\mathrm{G}$ and amoxycillin might be due to the production of $\beta$-lactamase enzyme by resistant strains of bacteria owing to their frequent use at the farm for mastitis control. On the other hand, higher sensitivity to enrofloxacin, cefotaxime, amoxycillin/ clavulanic acid, might be explained on the basis of their less frequent use at the farm. In vitro antimicrobial susceptibility is considered as a prerequisite for treatment. However, in vitro activity does not guarantee in vivo efficacy as pharmacokinetics of the antimicrobial substance greatly affects its suitability for mastitis treatment (Pyöräla, 2009).

The variation in the present study in the sensitivity pattern could be credited to the variation in sensitivity of different isolates in different geographical locations and resistance to commonly used antibacterials. Further, indiscriminate use of these drugs contribute to the increased resistance of different bacterial strains to commonly used antibacterials such as Ceftriaxone, Cefotaxime, Ceftriaxone/ Salbactum, Amoxycillin/ Sulbactam and streptomycin.

Sahoo et al., (2009) was of the opinion that antibacterial sensitivity test of different antibacterials varies widely from low to high sensitivity could be attributed to their prolonged and injudicious usage under field conditions. The current work enables selection of proper antibacterials for treatment of sub-clinical mastitis in the study area. Further, this study warrants usage of drugs at proper dosages and schedule to prevent further antibacterial resistance to different bacteria.

\section{Acknowledgements}

The authors would like to thanks Dean, College of Veterinary and Animal Sciences, GB Pant University of Agriculture \& Technology, Uttarakhand, India, for providing the research facilities.

\section{References}

Ali Z, Dimri U and Jhambh R. 2015. Prevalence and Antibiogram of Bacterial Pathogens From Subclinical Mastitis In Buffaloes. Buffalo, 34(1): 41-44.

Awandkar SP, Khode NV, Sardar VM and Mendhe MS. 2009. Prevalence and current antibiogram trend of mastitic agents in Udgir and its Vicinity, Maharashtra State, India. Int. J. Dairy Sci., 4(3): 117-122.

Bansal BK and Gupta DK. 2009. Economic analysis of bovine mastitis in India and Punjab-A Review. Indian J. Dairy Sci., 62(3): 337-45.

Bauer AW, Kieby WMM, Shrenis J.C and Turck M. 1966. Antibiotic susceptibility testing by a standardized single disc diffusion method. Am. J. Clin. Pathol., 45: 453-496.

Bhanot V, Chaudhri SS, Bisla RS and Singh H. 2012. Retrospective study on prevalence and antibiogram of mastitis in cows and buffaloes of eastern Haryana. Indian J. Anim. Sci., 46(2):160-163.

Bradley A J. 2002. Bovine mastitis: An evolving disease. Vet. J., 163:1-13.

Elsayed MS, El-Bagoury AM and Dawoud MA. 2015. Phenotypic and genotypic detection of virulence factors of Staphylococcus aureus isolated from 
clinical and subclinical mastitis in cattle and water buffaloes from different farms of Sadat City in Egypt. Vet. World, 8(9):1051-1058.

Hamed MI and Ziatoun AMA. 2014. Prevalence of Staphylococcus aureus subclinical mastitis in dairy buffaloes farms at different lactation seasons at Assiut Governorate, Egypt. Int. J. Livest. Res., 4(3): $21-28$

Jhambh R, Dimri U, Gopalakrishnan A, Singh $\mathrm{M}$ and Chhabra R. 2017. Prevalence and risk factors of subclinical mastitis in buffaloes at an organized dairy farm in western Haryana. Haryana Vet., 56(2): 189-193.

Keefe GP. 1997. Streptococcus agalactiae mastitis: A review. Can. Vet. J., 38: 429437.

Khan AZ, Khan A, Hayat CS, Munir Z and Ayaz U. 2004. Prevalence of mastitis in buffaloes and antibiotic sensitivity profiles of isolates. Pak. J. Life soc. Sci., 2(1):73-75.

Kumar M, Kumar R, Sharma A and Jain VK. 2007. Investigations on prevalence and oxidative stress aspects of mastitis in buffaloes. Ital. J. Anim. Sci., 6(2): 978979.

Pyöräla S. 2009. Treatment of mastitis during lactation. Irish Vet. J., 62: 40-44.

Quinn PJ, Carter ME, Markey B and Carter, G.R. 2004. Clinical Veterinary Microbiology, Mosby, Elsevier Limited, Philadelphia, USA.

Radostits OM, Blood DC, Gay CC and Constable PD. 2007. Veterinary
Medicine: Diseases of cow, buffalo, horse, sheep, goat and pig. 10th Edition, Saunders Elsevier Limited, Philadelphia, USA.

Sahoo SS, Sahoo N and Parida GS. 2009. Antibiogram of bacterial isolates from bovine subclinical mastitis. Indian. Vet. J., 86(12):1298-1299.

Sharma A and Sindhu N. 2007. Occurrence of clinical and subclinical mastitis in buffaloes in the State of Haryana (India). Ital. J. Anim. Sci., 6(2): 965-967.

Sharma N, Zul-I-Huma, Singh SG, Navjot, Sharma S, Gupta SK and Upadhyay SR. 2018. Prevalence of Clinical and Subclinical Mastitis in Buffaloes of Jammu Region. Internat. J. of Agri., Environ. and Biotech., (IJAEB), 11(2): 415-420.

Sumathi BR, Veeregowda BM and Gomes AR. 2008. Prevalence and antibiogram profile of bacterial isolates from clinical bovine mastitis. Vet. World, 1: 237-238.

Tripathi S. 2015. Epidemiological investigation and therapeutic evaluation of Azadirachta indica in bovine subclinical mastitis. Thesis submitted to GBPUAT, Pantnagar, Uttarakhand.

Viguier C, Arora, Gilmartin N, Welbeck K and O'Kennedy R. 2009. Mastitis detection: current trends and future perspectives. Trends Biotechnol., 27(8): 486-493.

Zhao X and Lacasse P. 2008. Mammary tissue damage during bovine mastitis: Causes and control. J. Anim. Sci., 86(1): 57-65.

\section{How to cite this article:}

Arpit Tyagi, Richa Arora, V.S. Rajora and Niddhi Arora. 2020. Antibiogram of Bacterial Isolates from Bubaline Subclinical Mastitis. Int.J.Curr.Microbiol.App.Sci. 9(11): 215-220. doi: https://doi.org/10.20546/ijcmas.2020.911.025 